\title{
LIQUIDITY ANALYSIS AND LEVERAGE OF RETURNS OF STOCK COMPANIES LISTED IN INDONESIA STOCK EXCHANGE (BEI)
}

\author{
Arizel 1), Irdha Yusra ${ }^{2)}$ \\ ${ }^{1,2)}$ Sekolah Tinggi Ilmu Ekonomi KBP \\ Email:arizel12011995@yahoo.co.id \\ Email: irdhayusra@gmail.com
}

\begin{abstract}
As the demand and supply of goods and services in the international market increases, many companies are racing to meet the demand. By attracting capital owners (investors) to invest their capital in the company, where the fund is a supporting factor in providing and creating a new product, the company can take a position in the international market and can develop in accordance with the objectives of the company. This study aims to determine the effect of Leverage ratio and Liquidity ratio on Stock Return. This research is included in the type of quantitative research. The population in this study is cement sub-sector manufacturing companies listed on the Indonesian stock exchange. The sample is 6 companies. The sampling technique used is purposive sampling. The data collected is processed using Eviews analysis tools. The data processing method used is multiple linear regression analysis.Based on the results of observation and data analysis on the effect of the current ratio and debt to equity ratio on stock returns using multiple linear regression analysis is not significant, it can be concluded that the current ratio shows a positive coefficient value of 0.006537 with a probability of more than 0.05 that is equal to 0.6901. For debt to equity ratio also shows a positive coefficient value that is equal to 0.116497 with a probability level of more than 0.05 that is 0.0954 .
\end{abstract}

Keywords: DER, CR and Stock Return

\begin{abstract}
ABSTRAK
Seiring meningkatnya permintaan dan penawaran produk barang dan jasa dalam pasar internasional, banyak perusahaan yang berpacu-pacu untuk memenuhi permintaan tersebut. Dengan menarik para pemilik modal (investor) menanamkan modalnya kepeda perusahaannya, dimana dana tersebut merupakan faktor penunjang dalam menyedikan dan penciptaan suatu produk baru, sehingga perusahaan tersebut dapat mengambil posisi di dalam pasar internasional dan bisa berkembang sesuai dengan tujuan perusahaan itu berdiri. Penelitianini bertujuan untuk mengetahui pengaruh rasio Leverage dan rasio Likuiditas terhadap Return Saham. Penelitian initermasukdalamjenispenelitianKuantitatif. Populasidalampenelitianiniadalah Perusahaan manufaktur sub sektor semen yang terdaftar di bursa efek Indonesia. Sampel yaitu 6 perusahaan .Teknikpengambilansampel yang digunakanadalah purposive sampling.Data yang dikumpulkandiolahmenggunakanalatanalisisEviews.MetodePegolahan data yang digunakanadalahanalisisregresilinear berganda.Berdasarkan hasil observasi dan analisis data mengenai pengaruh current ratio dan debt to equity ratio terhadap return saham menggunakan analisis regresi linear berganda ialah tidak signifikan, dapat
\end{abstract}


disimpulkan bahwa current ratio menunjukan nilai koefisien positif yaitu sebesar 0.006537 dengan probabilitas lebih dari 0.05 yaitu sebesar 0.6901. Untuk debt to equity ratiojuga menunjukan nilai koefisien positif yaitu sebesar 0.116497 dengan tingkat probabilitas lebih dari 0.05 yaitu 0.0954 .

Keywords: DER, CR dan Return Saham 


\section{PENDAHULUAN}

Seiring meningkatnya permintaan produk barang dan jasa dalam pasar internasional, banyak perusahaan yang berlomba - lomba untuk menyediakan permintaan tersebut. Dengan menarik para pemilik modal (investor) menanamkan modalnya kepeda perusahaannya, dimana dana tersebut merupakan faktor pendukung dalam menyedikan dan penciptaan suatu produk baru, sehingga perusahaan tersebut dapat mengambil tempat pada pasar internasional dan bisa berkembang sesuai dengan tujuan perusahaan itu berdiri. Hal ini juga terlihat dengan semakin banyaknya perusahaan baru yang berdiri dan semakin berkembabang sesuai dengan bertambahnya jumlah unit usaha ataupun ruang lingkup usahanya.

Pemerintah telah memberikan berbagai kemudahan untuk dapat lebih meningkatkan kegiatan ekonomi, seperti memberikan bantuan permodalan dan mempermudah izin bagi pelaku investor baru dalam menempatkan modalnya di indonesia. Mengingat modal sangatlah dibutuhkan bagi kelangsungan suatu usaha, hal ini juga yang merupakan kendala yang sering ditemui oleh perusahaan untuk berkembang dan masuk ke pasar internasional oleh terbatasnya modal yang dimiliki. Suatu perusahaan dapat menarik investor baru dengan listning di Bursa Efek Indonesia (BEI), tetapi tidak semua perusahaan mampu masuk ke pasar modal ini.

Pasar modal adalah alternatif untuk mempercepat pertumbuhan perusahaan. Hal ini karena pasar modal adalah instrumen keuangan yang sangat penting dalam sebuah perekonomian, yang berfungsi mempertemukan dana dari masyarakat ke sektor produktif (perusahaan). Peran intermediasi keuangan dari masyarakat ke unit usaha tersebut dimaksudkan untuk menunjang pertumbuhan perekonomian dalam suatu negara. Permadhy (2005) mengatakan pasar modal bermanfaat bagi perluasan usaha, memperbaiki struktur modal, mendorong laju pembangunan, mendorong investasi, dan/atau memperoleh dividen bagi yang memiliki saham dan bunga tetap atau bunga mengambang untuk pemegang obligasi.

Perusahaan manufaktur ialah jumlah emiten yang terbesar dibanding dengan jumlah emiten yang listing di BEI. Berdasarkan data yang diterbitkan oleh IDX jumlah total sebanyak 539 perusahaan, dan yang tergolong emiten manufaktur sebanyak 144 perusahaan, jika dipresentasekan 26,72\%. Terbagi atas tiga sektor yaitu Industri Barang Konsumsi, Aneka Industri dan Industri Dasar \& Kimia, yang terbagi menjadi 19 Sub Sektor. Dengan jumlah besar, perusahaan-perusahaan manufaktur memiliki pengaruh yang signifikan terhadap dinamika perdagangan saham di BEI. Dari itulah peneliti tertarik sehingga mengambil objek penelitian pada perusahaan manufaktur selain mengembangkan penelitian-penelitian yang terdahulu.

Dari berbagai rasio keuangan terdapat beberapa rasio dan informasi keuangan perusahaan yang dapat digunakan untuk memprediksi return saham. Rasio keuangan yang bisa dipakai untuk memprediksi return saham yaitu rasio likuiditas dan leverage. Dalam hal ini peneliti akan menggunakan Current Ratio (CR) dari rasio likuiditas dan Debt Equity Ratio (DER) dari rasio leverage.

Berdasarkan latar belakang tersebut dan bertitik tolak pada uraian tersebut maka peneliti tertarik untuk meneliti tentang "Analisis Likuiditas Dan Leverege terhadap Return Saham Pada Perusahaan Manufaktur Di Bursa Efek Indonesia 
(BEI)". Pemilihan objek perusahaan di Bursa Efek Indonesia karena peranan suatu likuiditas dan leverage sangat berpengaruh terhadap kinerja suatu perusahaan.

\section{Pengaruh Current Ratio Terhadap Return Saham}

Rasio likuiditas digunakan untuk mengetahui tingkat kemampuan di suatu perusahaa dalam memenuhi kewajiban jangka pendeknya. Current Ratio (CR) didapatkan dengan cara membandingkan nilai di aktiva lancar dengan pemenuhan kewajiban lancar di suatu perusahaan. Semakin tinggi nilai CR maka akan semakin baik tingkat kemampuan di suatu perusahaan dan untuk melunasi kewajiban atau hutang pada jangka pendeknya. Dan jika semakin baik tingkat kemampuan perusahaan untuk memenuhi dan melunasi kewajibannya atau hutang berarti akan semakin kecil pula risiko pada likuidasi yang dialami oleh perusahaan dengan kata lain akan semakin kecil risiko yang ditanggung oleh para investor atau pemegang saham di perusahaan.

Sangat penting bagi pemegang saham (investor) untuk dapat mengetahui bagaimana nilai CR nya, walaupun nilai tersebut hanyalah bersifat relativ (jangka pendek). Investor akan beranggapan bahwa perusahaan beroperasi dengan lancar dan baik, maka untuk menutupi kewajiban pada jangka pendeknya pada saat itu nilai CR meningkat dan nilai return saham pun juga akan mengalami perubahan peningkatan.

Hasil penelitian yang telah diteliti oleh (Nugroho, 2009) yang berjudul Analisis Pengaruh Informasi Fundamental Terhadap Return Saham (Studi Komparatif Di Sub Sektor Industri Otomotif Sub Sektor Industri Tekstil Sepanjang Periode pada Tahun 2003 Sampai Dengan Tahun 2007 Di BEI), menerangkan nilai CR memiliki effect yang positif dan signifikan terhadap return saham.

Penelitian selanjutnya dilakukan oleh (Prihantini, 2009) yang bertujuan untuk melihat pengaruh DER dan CR terhadap Return Saham. Dimana hasil dari penelitiannya mengatakan bahwa nilai CR sangat berpengaruh positif dan tingkat signifikannya terhadap return saham.

Ulupui (2005) telah melakukan penelitian tentang Analisis Pengaruh Rasio Likuiditas, Leverage, Aktivitas, dan Profitabilitas Terhadap Return Saham tahun 1999-2005. Metode yang digunakan ialah analisis regresi berganda, dimana hasil dari penelitiannya menjelaskan bahwa nilai CR berpengaruh positif dan juga signifikan terhadap grow return saham.

Berdasarkan argumentasi di atas, hipotesis pertama yang dapat di bangun adalah sebagai berikut :

H1: Current Ratio (CR) memiliki pengaruh positif dan juga signifikan terhadap pertumbuhan return saham.

\section{Pengaruh Debt To Equity Ratio Terhadap Return Saham}

Semakin tinggi nilai rasio DER maka akan menunjukkan tingkat pengembalian yang semakin kecil. Resiko yang harus ditanggung oleh para investor akan semakin tinggi karena tingkat hutang yang tinggi berarti biaya beban bungajuga akan semakin tinggi maka ini akan mengurangi resiko, dan ini berakibat pada penurunan return saham (Ang, 1997). 
Penelitian yang sudah dilakukan oleh (Widyarini, 2006). Yang berjudul Pengaruh Faktor yang Fundamental terhadap Kemampuan Return Saham Perusahaan Miscellaneous Industries Yang Terdaftar di Bursa Efek Jakarta pada Periode 2002-2003. Dengan menggunakan salah satu metode Analisis Regresi Berganda, dimana Hasil penelitiannya ialah menunjukkan bahwa DER akan berpengaruh positif dan signifikannya terhadap return saham.

Sejalan dengan penelitian yang telah dilakukan oleh (Prasetyo, 2005) tentang Analisis Pengaruh Kinerja Keuangan Perusahaan Terhadap Return Saham (Studi Kasus di Perusahaan yang masuk Indeks LQ 45 Periode 1999-2003). Dimana hasil dari penelitianya menunjukan bahwa DER akan berpengaruh positif dan signifikannya terhadap return saham.

Berdasarkan argumentasi di atas, hipotesis kedua yang dapat di bangun adalah sebagai berikut :

H2: Debt to Equity Ratio (DER) memiliki pengaruh positif dan juga signifikan terhadap pertumbuhan return saham.

\section{METODOLOGI PENELITIAN}

\section{Data dan Sampel}

Data dan Sampel penelitian ini dilakukan pada perusahaan manufaktur yang listed di BEI dengan periode pengamatan 2010 - 2017. Sampel di ambil dengan menggunakan metode Purposive Samplingyang didasarkan atas standar yang ditetapakan oleh peneliti adapun kriteria yabg digunakan adalah 1) perusahaan terdaftar di bursa efek indonesi. 2) Perusahaan yang bergerak di bidang sub sektor semen. 3) perusahaan yang memiliki laporan keuangan lengkap.

Dalam penelitin ini data return saham diperoleh dengan perhitungan menggunakan rumus dari data harga saham pada ICMD (Indonesian Capital Market Directory), Debt to Equity Ratio (DER), Current Ratio (CR) diperoleh dengan mengutip secara langsung dari Indonesia Capital Market Directory (ICMD). berikut :

Rincian variabel yang digunakan pada penelitian ini dapat dilihat dari tabel

Tabel 1

Defenisi Operasional Variabel Penelitian

\begin{tabular}{|c|c|c|c|c|}
\hline No & Variabel & Definisi & Pengukuran & Sumber \\
\hline 1 & $\begin{array}{l}\text { Return } \\
\text { Saham }\end{array}$ & $\begin{array}{l}\text { Ialahlogaritma } \\
\text { natural dari } \\
\text { perbandingan harga } \\
\text { saham perioda } \\
{\text { berikutnya }{ }_{i t+1} \text { dengan }} \\
\text { perioda saat ini }{ }_{i t} .\end{array}$ & $R_{i t}=\operatorname{Ln} \frac{P_{i t+1}}{P_{i t}}$ & $\begin{array}{l}\text { Husnan } \\
\text { (2001) }\end{array}$ \\
\hline
\end{tabular}




\begin{tabular}{|c|c|c|c|c|}
\hline 2 & $\begin{array}{c}\text { Current } \\
\text { Ratio }\end{array}$ & $\begin{array}{l}\text { Ialah perbandingan } \\
\text { aktiva lancar dengan } \\
\text { hutang lancar }\end{array}$ & $\begin{array}{l}C R \\
=\frac{\text { Aktiva Lancar }}{\text { Hutang Lancar }} \times 100 \%\end{array}$ & $\begin{array}{l}\text { Kasmir } \\
\text { (2008) }\end{array}$ \\
\hline
\end{tabular}

\begin{tabular}{cclll}
\hline 3 & Debt to & Ialahperbandingan & DER & Kasmir \\
Equity & $\begin{array}{l}\text { Total hutang } \\
\text { Ratio }\end{array}$ & $\begin{array}{l}\text { total hutang dengan } \\
\text { ekuitas }\end{array}$ & $=00 \%$ & (2008) \\
& R
\end{tabular}

Penelitian menggunakan program Eviews untuk memperoleh semua nilai yang diinginkan di model analisis regresi dan pengujian secara statistik. Pada penelitian ini, teknik analisa data yang dilakukan menggunakan teknik analisis regresi linier berganda bertujuan untuk mengolah dan membahas data yang telah diperolah dan menguji hipotesis yang diajukan.

Analsis regresi linier berganda ialah korelasi secara linier antara dua atau lebih variable independen $\left(\mathrm{X}_{1}, \mathrm{X}_{2}, \ldots . . \mathrm{X}_{\mathrm{n}}\right)$ dengan variable dependen $(\mathrm{Y})$. Analisis ini agar mengetahui arah hubungan antar variabel independen dengan variabel dependen apakah masing-masing variabel independen ini berhubungan positif atau berhubungan negatif dan untuk memperkirakan nilai dari variabel dependen kalua nilai variabel independen mengalami kenaikan atau penurunan. Data yang dipakai biasanya berasal dari intervall atau rasio.

Model persamaan regrei untuk memguji hipotesis dengan formula sebagai berikkut:

Keterangan:

$$
R i t=\alpha+\beta_{1} C R_{i t}+\beta_{2} D E R_{i t}+e
$$

Rit $=$ Return Saham Individual di periode $\mathrm{t}$

Crit $=$ Current Ratiodi periode $\mathrm{t}$

DERit $=$ Debt to Equity Ratiodi periode $\mathrm{t}$

$\alpha=$ Konstanta

$\beta=$ Koefisien regresi (nilai peningkatan ataupun penurunan)

$e \quad=$ Nilai Residual (Faktor Penggangu)

Untuk melihat pengaruh CR dan DER terhadap Return Saham maka digunakan Uji t. Uji t dipakai untuk menguji pengaruh variabel independen secara persial terhadap variabel dependen, yaitu pengaruh dari variabel independen (Current Ratio dan debt to equity ratio) terhadap variabel dependen (return saham) yang didasarkan di nilai probabilitas a $=0,05$ dengan kriteria pengujian sebagai berikut:

Jika probabilitas > 0,05 Ha ditolak, variabel independen tidak berpengaruh terhadap variabel dependen.

Jika probabilitas < 0,05 Ha diterima, variabel independen berpengaruh

HASIL DAN PEMBAHASAN terhadap variabel dependen. 


\section{Statistik Deskiptif Variabel Penelitian}

Berdasarkan hasil analisis deskriptif statistik, maka data karekteristik sampel yang digunakan didalam penelitian ini meliputi: jumlah sampel $(\mathrm{N})$, rata-rata sampel (mean), nilai maksimum, nilai minimum serta standar deviasi $(\sigma)$ untuk masing-masing variabel.

Tabel 2

Hasil Uji Deskripsi Statistik Variabel Penelitian

\begin{tabular}{ccccc} 
Variabel & Maksimum & Minimum & Mean & Standar Deviasi \\
\hline CR & 12.990 & 0.4600 & 3.2428 & 2.7362 \\
\hline DER & 1.1600 & 0.0500 & 0.3022 & 0.2606 \\
\hline R & 0.1845 & -0.0680 & 0.0078 & 0.0394 \\
\hline
\end{tabular}

Sumber : Data Diolah, Lampiran 2

Di tabel di atas memperlihatkan bahwa jumlah data yang dipakai dalam penelitian ini sebannyak 32 sampel data yang didapat dari laporan tahunan publikasi sektor manufakfur subsektor semen yang tercatat pada BEI periode 2010-2017. Data X1 (Current Ratio (CR) tertinggi (maksimum) ialah 12.990. Dimana nilai ini terdapat di perusahaan SMBR tahun 2014, dan nilai terendah (minimun) terdapat di perusahaan SMCB tahun 2016 dengan nilai 0.4600, kemudian rata-rata Current Ratio sebesar 3.2428. Sementara standar deviasi sebesar 2.7362 menunjukkan simpangan data yang relatif kecil, karena nilainya yang relatif kecil dari pada nilai mean-nya yaitu sebesar $2.7362<3.2428$.

Data X2 (Debt to Equity Ratio) DER tertinggi (maksimum) ialah 1.1600. Dimana nilai ini terdapat di perusahaan SMCB tahun 2017, dan nilai terendah (minimun) terdapat di perusahaan SMGR tahun 2010 dengan nilai 0.0500, kemudian rata-rata (Debt to Equity Ratio) DER sebesar 0.3022. Sementara standar deviasi sebesar 0.2606, menunjukkan simpangan data yang relatif kecil, karena nilainya yang relatif kecil dari pada nilai mean-nya yaitu $0.2606<0.3022$.

Data Y (return saham) mempunyai nilai tertinggi (maksimum) ialah 0.1845. Dimana nilai ini terdapat di perusahaan SMBR tahun 2016 dan nilai terendah(minimun) terdapat di perusahaan SMCB tahun 2015 dengan nilai 0.068 , kemudian rata-rata 0.0078 dengan nilai standar deviasi sebesar 0.0394 menunjukkan simpangan data yang relatif besar, karena nilainya yang lebih besar dari nilai meannya yaitu $0.0394>0.0078$.

\section{Uji Asumsi Klasik}

a. Uji Normalitas Data

Tabel3

Hasil Uji Normalitas Data 1

\begin{tabular}{cccc}
\hline Variabel & N & Jarque-Bera & Probabilitas \\
\hline CR & 32 & 2.7755 & 0.0000 \\
\hline DER & 32 & 3.3666 & 0.0000 \\
\hline R & 32 & 2.0147 & 0.0000 \\
\hline \multicolumn{5}{l}{ Sumber : Data diolah, Lampiran 2 }
\end{tabular}


Dilihat dari Tabel 4.2 diatas pada probabilitas untuk semua variabel bernilai nol, berarti data untuk setiap variabel tidak normal karena untuk syarat normal adalah probability jargue-bera > 0,05. Menurut (Murti, 2013) Untuk menormalkan data, maka data mentah dilakukan pengolahan kembali dengan menggunakan transformasi square root, transformasi square root disebut juga dengan transformasi akar kuadrat dengan rumus $=\mathrm{SQRT}($ Variabel+0,5). Maka hasil dari pengolahan transformasi di lihat di bawah ini

Tabel 4

Hasil Uji Normalitas Data 2

\begin{tabular}{cccc}
\hline Variabel & $\mathbf{N}$ & Jarque-Bera & Probabilitas \\
\hline CR & 32 & 3.6770 & 0.1590 \\
\hline DER & 32 & 5.2755 & 0.0715 \\
\hline R & 32 & 0.6242 & 0.7318 \\
\hline
\end{tabular}

Sumber : Data diolah, Lampiran 2

Melalui hasil pengujian normalitas di atas, disimpulkan bahwa seluruh data variabel dalam penelitian ini (current ratio (CR), Debt to Equity Ratio (DER), dan return saham) telah terdistribusi secara normal.

b. Uji Multikolinearitas

Tabel 5

Hasil Uji Multikolinearitas

\begin{tabular}{ccc}
\hline $\mathrm{V}$ & $\mathrm{X} 1$ & $\mathrm{X} 2$ \\
\hline $\mathrm{CR}$ & 1 & -0.5874 \\
\hline DER & -0.5874 & 1 \\
\hline
\end{tabular}

Sumber : Data diolah, Lampiran 3

Pada tabel di atas, nilaikorelasiantara variabel X1 (current ratio) dengan $\mathrm{X} 2$ (debt to equity ratio) bernilai dibawah 0 yaitu -0.5874 dengan korelasi bersifat lemah. Dengan demikian berdasarkan hasil uji multikolinearitas diatas dapat disimpulkan bahwa data variabel current ratio dengan debt to equity ratio tidak terjadi hubungan multikolinearitas.

\section{c. Uji Heteroskedastisitas}

Tabel6

Hasil Uji Heteroskedastitas

\begin{tabular}{lccc}
\hline \multicolumn{1}{l}{ F- } & 0.236332 & Prob. & 0.9429 \\
statistic & & $\mathrm{F}(5,26)$ & \\
\hline Obs*R- & 1.391124 & Prob. & 0.9253 \\
squared & & Chi- & \\
& & Square(5) & \\
\hline
\end{tabular}

Sumber : Data diolah, Lampiran 4

Pada tabel di atas, terlihat bahwa tidak terjadi heteroskedastisitas karena nilai probability Obs*R-squared yaitu $0.9253>0.05$. 


\section{d. Uji Autokorelasi}

Tabel7

Hasil Uji Autokorelasi

\begin{tabular}{ccc} 
Model & Durbin-Watson \\
\cline { 2 - 3 } & \multicolumn{2}{c}{ Hasil Uji Autokorelasi } \\
\hline
\end{tabular}

Sumber : Data diolah, Lampiran 5

Pada tabel diatas, terlihat bahwa nilai model dari durbin-watson adalah 1.8929. Berdasarkan hasil uji autokorelasi diatas dapat disimpulkan bahwa tidak terjadi autokorelasi karena nilai durbin-watson antara $-2<1.8929<2$.

Analisis Regresi Linear Berganda

Tabel 8

HasilUjiRegresi Linear Berganda

\begin{tabular}{lllll}
\hline \hline Variable & Coefficient & Std. Error & t-Statistic & Prob. \\
\hline \hline $\mathrm{C}$ & 0.576985 & 0.080012 & 7.211219 & 0.0000 \\
$\mathrm{X} 1$ & 0.006537 & 0.016231 & 0.402748 & 0.6901 \\
$\mathrm{X} 2$ & 0.116497 & 0.067590 & 1.723583 & 0.0954 \\
\hline \hline R-squared & 0.108743 & Mean dependent var & 0.689663 \\
Adjusted R-squared & 0.047277 & S.D. dependent var & 0.048229 \\
S.E. of regressio & 0.047076 & Akaike info criterion & -3.185065 \\
Sum squared resid & 0.064267 & Schwarz criterion & -3.047652 \\
Log likelihoo & 53.96103 & Hannan-Quinn criter. & -3.139516 \\
Fstatistic & 1.769165 & Durbin-Watson stat & 1.892963 \\
Prob & 0.188382 & & \\
\hline \hline
\end{tabular}

Sumber : Eviews

Nilai konstanta sebesar 0.576985 berarti bahwa nilai return saham adalah sebesar 0.576985 dengan asumsi variabel lain bernilai nol. Nilai koefisien regresi X1 (current ratio) sebesar 0.006537 maksudnya adalah setiap peningkatan 1\% current ratio, maka akan mengakibatkan peningkatan nilai koefisien return saham sebesar 0,65\%. Dalam hal ini faktor-faktor lain yang mempengaruhi return saham dianggap tetap.

Nilai koefisien regresi $x 2$ (debt to equity ratio) sebesar 0.116497 maksudnya adalah setiap peningkatan $1 \%$ debt to equity ratio, maka akan mengakibatkan peningkatan nilai koefisien return saham sebesar 11,6\%. Dalam hal ini faktor-faktor lain yang mempengaruhi return saham dianggap tetap.

\section{Uji Hipotesis}

a. Uji F (Simultan)

Uji F digunakan untuk menguji pengaruh variable independen yaitu cuurent rartio dan debt to equity ratio secara bersama-sama terhadap variable dependen yaitu reaksi investor. Dari hasil pengolahan data dihasilkan nilai $F$-Statistic sebesar 1.769165 dengan nilai signifikansi probability $F$-Statistic adalah0.188382, tingkat probabilitasnya lebih besar dari 0.05 atau $<0.05$. Hal tersebu tmengindikasikan bahwa semua atau salah satu dari variable independen (cuurent rartio dandebt to 
equity ratio) tidak berpengaruh secara signifikan terhadap variable dependen (return saham).

\section{b. Uji T (Parsial)}

Uji tdigunakan untuk menguji pengaruh variable independen secara parsial terhadap variable dependen, yaitu pengaruh dari variable independen (cuurent rartio dandebt to equity ratio) terhadap variable dependen (reaksi investor). Dari hasil pengolahan data dihasilkan current ratio menunjukan thitung 0.402748 dengan nilai yang tidak signifikan 0.6901 lebih dari tingkat alpha 0.05 dan koefisien $\beta$ sebesar 0.006537 menunjukan nilai positif. Hal ini berarti bahwa current ratio tidak berpengaruh terhadap return saham. Untuk debt to equity ratio menunjukan $t_{\text {hitung }}$ 1.723583 dengan nilai yang signifikan 0.0954 besar dari tingkat alpha 0.05 dan koefisien $\beta$ sebesar 0.116497 menunjukan nilai positif. Hal ini berarti bahwa debt to equity ratio tidak berpengaruh terhadap return saham.

\section{Uji $\mathbf{R}^{2}$}

$\mathrm{R}^{2}$ (R-Square) digunakan untuk mengukur seberapa besar proporsi variasi dari variable independen secara bersama-sama dalam mempengaruhi variable dependen. Dari hasil pengolahan data ditemukan nilai $R$-squared 0.047277 ini berarti bahwa variabel bebas cuurent rartio dan debt to equity ratio mem pengaruhi return saham sebesar 4,72\% sedangkan sisanya 95,28\% dipengaruhi oleh faktor lain

\section{Pembahasan}

\section{Pengaruh Current Ratio terhadap Return Saham}

Hasil pengujian parsial (uji t) antara current ratio terhadap return saham menhasilkan thitung sebesar 0.402748 dengan nilai signifikan sebesar 0.6901 yang berada diatas 0,05 . Hal ini menjelaskan bahwa tidak ada pengaruh variabel current ratio secara parsial kepada return saham. Berdasarkan persamaan regresi juga terlihat bahwa koefisien untuk variabel CR bernilai 0.006537, sehingga dapat dijelaskan bahwa pengaruh yang dihasilkan oleh variabel CR terhadap return saham adalah tidak signifikan. Dengan demikian disimpulkan hipotesis pertama ditolak.

Hasil ini berbeda dengan Penelitian yang sudah dilakukan oleh (Widyarini, 2006). Yang berjudul Pengaruh Faktor yang Fundamental terhadap Kemampuan Return Saham Perusahaan Miscellaneous Industries Yang Terdaftar di Bursa Efek Jakarta pada Periode 2002-2003. Dengan menggunakan salah satu metode Analisis Regresi Berganda, dimana Hasil penelitiannya ialah menunjukkan bahwa DER akan berpengaruh positif dan signifikannya terhadap return saham dan juga penelitian yang telah dilakukan oleh (Prasetyo, 2005) tentang Analisis Pengaruh Kinerja Keuangan Perusahaan Terhadap Return Saham (Studi Kasus di Perusahaan yang masuk Indeks LQ 45 Periode 1999-2003). Dimana hasil dari penelitianya menunjukan bahwa DER akan berpengaruh positif dan signifikannya terhadap return saham.

Ini mungkin disebabkan oleh objek perusahaan yang berbeda, dan standarstandar yang digunakan dalam penarikan sampel pada objek penelitian. Sehingga hasil penelitian ini menerangkan bahwa CR tidak berpengaruh terhadap return 
saham, yang mana hasil penelitian ini sama dengan penelitian yang dilakukan oleh Hernendiastoro (2005), Sulaiman dan Handi (2008), Prihantini (2009), Farkhan dan Ika (2012) serta Prasetya dan Atmadja (2014) yang menerangkan bahwa Current Ratio tidak berspengaruh secara signifikan terhadap return saham.

\section{Pengaruh Debt to Equity Ratio terhadap Return Saham}

Hasil pengujian parsial (uji t) antara DER terhadap return saham menerangkan thitung sebesar 1.723583 dengan nilai signifikan sebesar 0.0954 yang berada diatas ini berarti tidak ada pengaruh variabel Debt to Equity Ratio secara parsial kepada return Saham. Berdasarkan persamaan regresi terlihat bahwa koefisien variabel DER bernilai positif 0.116497, sehingga dapat diartikan bahwa pengaruh yang dihasilkan oleh DER kepada Return Saham adalah tidak signifikan. Dengan itu dapat disimpulkan hipotesis kedua ditolak.

Hasil ini berbeda dengan Penelitian yang sudah dilakukan oleh (Widyarini, 2006). Yang berjudul Pengaruh Faktor yang Fundamental terhadap Kemampuan Return Saham Perusahaan Miscellaneous Industries Yang Terdaftar di Bursa Efek Jakarta pada Periode 2002-2003. Dengan menggunakan salah satu metode Analisis Regresi Berganda, dimana Hasil penelitiannya ialah menunjukkan bahwa DER akan berpengaruh positif dan signifikannya terhadap return saham. Dan penelitian yang telah dilakukan oleh (Prasetyo, 2005) tentang Analisis Pengaruh Kinerja Keuangan Perusahaan Terhadap Return Saham (Studi Kasus di Perusahaan yang masuk Indeks LQ 45 Periode 1999-2003). Dimana hasil dari penelitianya menunjukan bahwa DER akan berpengaruh positif dan signifikannya terhadap return saham.

Ini mungkin disebabkan oleh objek perusahaan yang berbeda, standarstandar yang digunakan dalam penarikan sampel pada objek penelitian. Dan periode dalam penelitian yang berbeda juga. Sehingga hasil penelitian ini menerangkan bahwa CR tidak berpengaruh terhadap return saham, Hasil analisis ini sama dengan hasil kajian yang dibuat oleh Rahayu (2003), Julliumursyida dan Gazali (2008), Widayanti (2012), Farkhan dan Ika (2012) serta Malintan dan Herawati (2013) yang menyatakan bahwa DER tidak berpengaruh singnifikan terhadap return saham.

\section{Simpulan}

Berdasarkan hasil observasi dan analisis data mengenai pengaruh current ratio dan debt to equity ratio terhadap return saham menggunakan analisis regresi linear berganda, dapat disimpulkan bahwa current ratio menunjukan nilai koefisien positif yaitu sebesar 0.006537 dengan probabilitas lebih dari 0.05 yaitu sebesar 0.6901 . Untuk debt to equity ratio juga menunjukan nilai koefisien positif yaitu sebesar 0.116497 dengan tingkat probabilitas lebih dari 0.05 yaitu 0.0954.Berdasarkan hasil tersebut dapat ditarik kesimpulkan bahwa cuurent ratio dan debt to equity ratio tidak berpengaruh terhadap return saham. 


\section{UCAPAN TERIMA KASIH}

Dalam penulisanpenelitianini, penulis menyadari tanpa adanya bimbingan dan bantuan dari berbagai pihak, penulis belum tentu dapat menyelesaikan penelitianini. Untuk itu ucapan terima kasih yang sebesar-besarnya penulis sampaikan kepada: Bapak Febryandhie Ananda, SE, M.Si, selakuketua STIE "KBP" Padang, yang membantu dan memberi saran bagi penulis.Ibu Febsri Susanti, SEI, MM selaku Ketua Prodi Manajemen STIE“KBP" Padang yang selalu memberikan motivasi dan bimbingannya.Dosen Pembimbing Proposal Skripsi Bapak Irdha Yusra, SE, M.Sc yang dengan kesabaran membimbing dan memberi arahan serta masukan yang sangat berguna bagi penulis sehingga skripsi ini dapat terselesaikan.

\section{DAFTAR PUSTAKA}

Ang, Robert. (1997). Buku Pintar: "Pasar Modal Indonesia". Mediasoft Indonesia, Jakarta.

Angraini, I., \& Yusra, I. (2019). Pendekatan data panel terhadap return saham: studi empiris pada perusahaan LQ45. INA-Rxiv.

Brigham, W. E. F., dan Houston, J. F. (1998). Dasar-Dasar Manajemen Keuangan. Edisi Ke-8. Jakarta: Erlangga.

Danil, A., \& Yusra, I. (2019). Pengaruh kausal antara ukuran perusahaan, nilai buku dan likuiditas saham di Bursa Efek Indonesia. INA-Rxiv.

Fahmi, Irfan., dan Hadi, Y. L. (2009). Teori Portofolio dan Analisis Investasi. Alfabeta, Bandung.

Farkhan dan Ika. (2012). Pengaruh Rasio Keuangan Terhadap Return Saham Perusahaan Manufaktur di BEI. Value Added, Vol 9, No. 1.

Ghozali, Imam. (2005). Aplikasi Analisis Multivariate Dengan Program SPSS. Badan Penerbit Universitas Diponegoro, Semarang.

Ghozali, Imam. (2011). Aplikasi Analisis Multivariate Dengan Program SPSS. Badan Penerbit Universitas Diponegoro, Semarang.

Gujarati, D. N. (2003). Basic Econometrics. 4th edition. McGraw-Hill International Edition, Economics Series.

Hadya, R. (2013a). Pengaruh Harga dan Risiko Saham Terhadap Likuiditas Saham Pada Perusahaan-Perusahaan Yang Terdaftar Di Bursa Efek Indonesia. Jurnal KBP, 1(2), 208-231.

Hadya, R. (2013b). Pengaruh Harga dan Risiko Saham Terhadap Likuiditas Saham Pada Perusahaan-Perusahaan Yang Terdaftar Di Bursa Efek 
Indonesia. Jurnal KBP, 1(2), 208-231. Retrieved from https://akbpstie.ac.id/cmsz/medias/file/9. rizka hadya.pdf

Hadya, R. (2014a). Analisis likuiditas, solvabilitas, nilai pasar dan return saham: studi empiris pada perusahaan sektor perbankan yang terdaftar di Bursa Efek Indonesia. Jurnal Riset Manajemen Dan Akuntansi, 3(1), 107-118.

Hanafi, D., \& Yusra, I. (2019). Tangibility, liquidity, growth opportunity, dan leverage: studi pada perusahaan terdaftar di Bursa Efek Indonesia. INA-Rxiv, (2001).

Harjito, Agus dan Martono. (2008). Manajemen Keuangan. Ekonisia, Yogyakarta.

Helfert, E.A., (1998). Teknik Analisis Keuangan. Erlangga, Jakarta.

Hernendiastoro, Andre. (2005). Pengaruh Kinerja Perusahaan Dan Kondisi Ekonomi Terhadap Return Saham Dengan Metode Intervalling (Studi Kasus Pada Saham-Saham LQ 45). Universitas Dipongoro, Semarang.

Husnan, Suad. (2002). Dasar-dasar Teori Portofolio dan Analisis Sekuritas. Yogyakarta: BPFE, UGM.

Husnan, Suad. (2005). Managemen Keuangan Teori dan Penerapan (keputusan jangka pendek) Edisi Kelima, Yogyakarta: BPFE.

Jogiyanto. (2007). Teori Portofolio dan Analisis Investasi, Edisi Keempat, Cetakan Pertama. Yogyakarta: BPFE.

Julliumursyida, Muammar, Wahyudin dan Gazali. (2008). Pengaruh Kinerja Keuangan Manufaktur Terhadap Return Saham di BEJ, Media Riset Akuntansi, Auditing dan Informasi. Vol 8 No. 1.

Kasmir. (2008). Analisis Laporan Keuangan. PT. Raja Grafindo Persada, Jakarta.

Kurniawan, A., \& Yusra, I. (2019). Apakah profitabilitas dan nilai buku berdampak terhadap return saham?: studi empiris pada perusahaan LQ45. INA-Rxiv.

Machfoedz, M. (1989). Akuntansi Manajemen. Yogyakarta: BPFE.

Malintan, R., dan Herawati, T. (2013). Pengaruh Current Ratio, Debt To Equity Ratio, Price Earning Ratio dan Return On Asset Terhadap Return Saham Perusahaan Pertambangan Yang Terdaftar di BEI Tahun 2005-2010. Jurnal Ilmiah Mahasiswa Akuntansi S1, FEB, Vol 2 No. 4.

Mulfita, A., \& Yusra, I. (2019). Analisis regresi data panel terhadap likuiditas saham di Indonesia. INA-Rxiv. 
Munawir. (2007). Analisis Laporan Keuangan, Edisi Keempat. Yogyakarta: Liberty.

Munawir. (2011). Analisis Laporan Keuangan, Edisi Kesebelas. Yogyakarta; Liberty.

Murti B, (2013). Prinsip dan Metode Riset Epidemiologi. Edisi ke 3. Gadjah Mada University. Yogyakarta.

Nugroho, Inung Adi. (2009). Analisis Pengaruh Informasi Fundamental Terhadap Return Saham (Studi Komparatif Pada Sub Sektor Industri Otomotif Sub Sektor Industri Tekstil Sepanjang Periode Tahun 2003 - 2007 di BEI). Tesis. Universitas Diponegoro, Semarang.

Permadhy, Yul Tito. (2005). Pengambilan Keputusan Berinvestasi di Pasar Modal. http://jurnal.pdii.lipi.go.id/admin/jurnal/21053843.pdf. Tanggal akses 01 Juli 2017.

Prasetya, I. Putu. Eva., Mode Pradana Adiputra., dan Ananta Wikrama Tungga Almadja. (2014). Pengaruh Current Ratio (CR), Debt to Equity Ratio (DER) dan Return On Asset (ROA) terhadap return saham pada Perusahaan Transportasi yang Terdaftar di Bursa Efek Indonesia. Jurnal Ilmiah Mahasiswa Akuntansi S1, Vol 2, No.

Prasetyo, T.B. (2005). Analisis Pengaruh Kinerja Keuangan Perusahagan Terhadap Return Saham (Studi Kasus Pada Perusahaan Yang Masuk Indeks LQ 45 Periode 1999-2003). Universitas Diponegoro, Semarang.

Prawirosentono, Suyadi. (2001). Manajemen Operasi. Bumi Aksara, Jakarta.

Prihantini, Ratna. (2009). Analisis Pengaruh Inflasi, Nilai Tukar, ROA, DER dan CR Terhadap Return Saham (Studi Kasus Saham industri Real Estate and Property yang terdaftar di Bursa Efek Indonesia Periode 2003-2006). Universitas Diponegoro, Semarang.

Putra, Adhi Kusuma R dan Suryono, B. (2014). Pengaruh Kinerja Keuangan Terhadap Return Saham Pada Perusahaan Manufaktur Yang Terdaftar Di Bursa Efek Indonesia Periode 2010-2012. Jurnal Informasi, Perpajakan, Akuntansi Dan Keuangan Publik. Sekolah Tinggi Ilmu Ekonomi Indonesia (STIESIA).

Putra, I., \& Yusra, I. (2019). Analisis likuiditas saham menggunakan regresi data panel. INA-Rxiv.

Rahayu M, I. K. A. (2003). Analisis Pengaruh Kinerja Keuangan Return Saham Di BEI Periode 1999-2001. Doktoral Dissertation, Program Pascasarjana Universitas Diponegoro. 
Restiyani, D. (2006). Analisis Pengaruh Faktor Fundamental Terhadap Return Saham (Study Kasus Pada Perusahaan Otomotif dan Komponennya di BEJ Periode 2001-2004). Universitas Diponegoro, Semarang.

Sari, N. N., \& Yusra, I. (2018). Analisis Likuiditas, Leverage dan Kebijakan Dividen berdasarkan Siklus Hidup Perusahaan pada Saham LQ45. INA-Rxiv.

Sartono, R.A . (2001). Manajemen Keuangan Teori Dan Aplikasi. BPFE, Yogyakarta.

Sawir, Agnes. (2009). Analisis Kinerja Keuangan dan Perencanaan Keuangan Perusahaan. PT. Gramedia Pustaka Utam, Jakarta.

Sugiyono. (2012). Metode Penelitian Kuantitatif Kualitatif dan R\&B. Alfabeta,Bandung.

Sulaiman, dan Handi, Ana. (2008). Pengaruh Kinerja Keuangan Terhadap Return Saham Pada Perusahaan Manufaktur di BEJ. Jurnal Penelitian Dan Pengembangan Akuntansi, Vol: 2 No.

Susilowati, Yeye dan Turyanto, T. (2011). Reaksi Signal Rasio Profitabilitas dan Rasio Solvabilitas terhadap Return Perusahaan. Jurnal Dinamika Keuangan Dan Perbankan 3(1), Hal: 17-37.

Syamsuddin, Lukman. (2011). Manajemen Keuangan Perusahaan. Jakarta: Raja Grafindo Persada.

Tandelilin, Edvardus. (2007). Analisis investasi dan Manajemen Portofolio. BPFE, Yogyakarta.

Thamrin, Yurlis. (2012). Analisis Current Ratio ( Cr ) Dan Debt Equity Ratio ( Der ) Terhadap Return Saham Perusahaan Manufaktur Yang Terdaftar Di Bursa Efek Indonesia. Fakultas Ekonomi dan Bisnis Universitas Hasanuddin.

Ulupui, I. G. K.A. (2005). Analisis Pengaruh Rasio Likuiditas, Leverage, Aktivitas, dan Profitabilitas Terhadap Return Sahamtahun 1999-2005. Skripsi. Fakultas Ekonomi Universitas Udayana.

Widayanti, Novi Wulandari dan Dianita, F. (2012). Pengaruh Rasio Leverage, Profitabilitas, Likuiditas terhadap Return Saham Perusahaan Aneka Industri yang terdaftar di BEI Periode 2003-2008. Relasi Jurnal Ekonomi.

Widyarini, F. (2006). Pengaruh Faktor Fundamental terhadap Return Saham Perusahaan Miscellaneous Industries Yang Terdaftar Di Bursa Efek Jakarta Periode 2002-2003. Universitas Diponegoro, Semarang.

Wild, John. (2005). Accounting Economics. Translation Penerbit PT. Gramedia 
Pustaka Umum, Jakarta.

Winarno, Wahyu Wing. (2011). Analisa Ekonometrika statistika dengan Eviews. STIM YKPN, Yogyakarta.

Yulianti, Y. D., \& Yusra, I. (2019). Pergerakan indeks harga saham gabungan sebagai dampak dari variabel makro. INA-Rxiv, 1-11. 